Magdalena Kusior $\mathrm{OP}^{1}$

Katolicki Uniwersytet Lubelski Jana Pawła II

\title{
Nowa ewangelizacja w Kościele
}

Misja ewangelizacyjna wypływa ze źródła, jakim jest Trójca Przenajświętsza. Jesteśmy Kościołem „posłanym”, i to posłanie jest permanentne. W Orędziu i Propositiones ${ }^{2}$ szczególnie zwraca się uwagę na to, jaki jest Kościół, w którym mamy się odnaleźćc ${ }^{3}$. Nowa misja stwarza potrzebę nowego modelu bycia Kościołem i stawania się coraz bardziej „Kościołem domowym” ${ }^{4}$, będącym wprost zwiastowaniem osoby Jezusa Chrystusa w tym celu, by człowiek stanął przed koniecznością wyboru: za albo przeciw ${ }^{5}$. Taki Kościół niesie z sobą doświadczenie jedności; ta jedność jest wielowymiarowa ${ }^{6}$.

1 Siostra Magdalena Kusior OP - mgr lic. teologii, katechetka w Zespole Szkół nr $11 \mathrm{w}$ Lublinie. Absolwentka studiów podyplomowych w zakresie duchowości katolickiej na Katolickim Uniwersytecie Lubelskim i doktorantka tego wydziału, E-mail: sr.magdalenaop@gmail.com.

2 Orędzie ojców synodalnych i 58 Propositiones to dwa teksty, które zostały skierowane do ojca świętego po synodzie Nowa ewangelizacja dla przekazu wiary. Zwykle jest to tekst łaciński do wyłącznej dyspozycji papieża.

3 Por. G. Ryś, Kierunki nowej ewangelizacji na podstawie wskazań Synodu Biskupów, „Via Consecrata" (2013) nr 1-2, s. 9.

4 Por. M. Chiaro, Per una nuova evangelizzazione, „Testimoni” (2011) nr 6, s. 3.

5 Zob. A. Sepioło, Nowa ewangelizacja. Śladami Jana Pawła II, w: Nowa ewangelizacja - kerygmatyczny impuls w Kościele, red. P. Sowa, K. Kaproń, Gubin 2012, s. 138.

6 Por. G. Ryś, Kierunki nowej ewangelizacji..., dz. cyt., s. 10. 
Jedna z konferencji episkopatu w następujący sposób definiuje ewangelizację: „Ewangelizacja jest manifestacją życia i witalności Kościoła. Wspólnota stała się Kościołem, kiedy ożywiona Duchem Świętym w dniu Pięćdziesiątnicy wyszła z Wieczernika. Dlatego też ewangelizacja nie może być postrzegana jako jedna z form aktywności Kościoła, ale jako manifestacja samej jego istoty i misji, znak obecności Ducha Świętego, który ożywia i prowadzi”"

\section{Definicja i wyzwania nowej ewangelizacji}

Głoszenie Dobrej Nowiny jest tym rodzajem ewangelizacji, którego Jezus uczył swoich uczniów najpierw. Wysyłając dwunastu po raz pierwszy z misją ewangelizacyjną, mówił do nich wyraźnie: „Nie idźcie do pogan i nie wstępujcie do żadnego miasta samarytańskiego. Idźcie do owiec, które poginęły z domu Izraela! Idźcie i głoście: «Bliskie już jest królestwo niebieskie». Uzdrawiajcie chorych, wskrzeszajcie umarłych, oczyszczajcie trędowatych, wypędzajcie złe duchy! Darmo otrzymaliście, darmo dawajcie!" (Mt 10, 5nn) ${ }^{8}$.Ci, którzy Go słuchają, mają poczucie czegoś kompletnie nowego! I to właśnie tę reakcję i doświadczenie słuchaczy drobiazgowo opisuje Ewangelista: „starą" prawdę o królestwie Boga mieszkańcy Kafarnaum - w spotkaniu z Jezusem - odkrywają ze zdumieniem jako „nową naukę”. Dlaczego nową? „Bo z mocą” tak tłumaczy ostatni werset naszej perykopy św. Hieronim w Wulgacie: „Nowa jakaś nauka, bo z mocą i duchom nieczystym rozkazuje..."'.

Ewangelizacja to „ewangelia - akcja”, działanie Ewangelii albo - mówiąc lepiej - Ewangelia w akcji, która przez wiele wieków nie funkcjonowało w kościelnym słowniku, dlatego dzisiaj trzeba odzyskać utracony teren za pomocą autentycznej integralnej ewangelizacji, która ustanowi niebo nowe i ziemię nową (zob. Ap 21, 1). Ewangelizacja musi oznaczać

7 J. Moens, Na czym polega nowa ewangelizacja, w: Nowa ewangelizacja - kerygmatyczny impuls w Kościele, dz. cyt., s. 19-20.

8 Por. G. Ryś, Jezusowa nowa ewangelizacja, w: Nowa ewangelizacja - kerygmatyczny impuls w Kościele, dz. cyt., s. 13.

9 Zob. G. Ryś, Jezusowa nowa ewangelizacja, dz. cyt., s. 15. 
Dobrą Nowinę ${ }^{10}$, ciągłe poszukiwanie nowych dróg mających źródła w Ewangelii ${ }^{11}$, rezygnację ze schematów i działań, które nie przynoszą obfitych owoców, by przyjąć nowe bukłaki dla nowej ewangelizacji ${ }^{12}$. Często wymaga ona radykalnego nawrócenia w wymiarze egzystencjalnym i zmiany dotychczasowych form duszpasterskich wyrażenia Ewangelii, które są w stanie dotrzeć do odbiorcy w zrozumiałym dla nich języku. Aby mogła zaistnieć nowa ewangelizacja, konieczne są nowy impuls i nowy zapał misyjny ${ }^{13}$. Nowa ewangelizacja, podobnie jak każda misja, wypływa z pewnej relacji, a nie własnej inicjatywy, nie może tu zabraknąć świadomości, że jest się posłanym w służbie Bogu i ludziom. Tylko wtedy życie oparte na głębokim doświadczeniu Boga przemienia się w ewangelizację ${ }^{14}$.

U wielu ludzi pojawia się lęk, gdy tylko zaczyna się mówić o potrzebie zmian. Zmiany niosą ze sobą nowość, w której nie wiadomo, czy nie zostanie utracona dotychczasowa pozycja, ponieważ dokonuje się bezkompromisowe nawrócenie, autentyczna przemiana myślenia, bezgraniczne zaufanie $\mathrm{Bogu}^{15}$. Zarówno nawrócenie, jak i nowa ewangelizacja są ze sobą bardzo blisko spokrewnione. Czasami potrzeba odważnych decyzji, aby się nawrócić ${ }^{16}$. Nowa ewangelizacja jest powołana do tego, żeby być głęboką reformą, chociaż z pewnością spotka się z dużym oporem, swoistą kontrreformacją ${ }^{17}$.

Istnieje potrzeba wyjaśnienia znaczenia przymiotnika „nowa” użytego w wyrażeniu „nowa ewangelizacja”. Okazuje się, że nie jest ona tak nowa. Wiele krajów wskazuje, że proces ten zaczął się u nich o wiele

10 J. H. Prado Flores, Nowi ewangelizatorzy dla nowej ewangelizacji, przekł. B. Jakubowski, Poznań 2013, s. 33.

11 M. Figura, Nowa ewangelizacjajako centralne zadanie Kościoła, w: Nowa ewangelizacja, red. L. Balter, Poznań 1993, s. 16 (Kolekcja Communio, 8).

12 J. H. Prado Flores, Nowi ewangelizatorzy dla nowej ewangelizacji, dz. cyt., s. 21.

13 J. Moens, Na czym polega nowa ewangelizacja, dz. cyt., s. 22.

14 J. Carballo, Nie lękajcie się! Idźcie i dawajcie świadectwo: Pan zmartwychwstał, w: Nowa ewangelizacja - kerygmatyczny impuls w Kościele, dz. cyt., s. 128.

15 A. Godnarski, Potrzebujemy ognia Ducha Świętego, w: Nowa Ewangelizacja-kerygmatyczny impuls w Kościele, dz. cyt., s. 7.

16 J. Zdrzałek, Nawrócenie jako droga nowej ewangelizacji, „Via Consecrata” 2013 nr 1-2, s. 52.

17 J. H. Prado Flores, Nowi ewangelizatorzy dla nowej ewangelizacji, dz. cyt., s. 40. 
wcześniej, np. Konferencja Episkopatu Portugalii z dużym poczuciem humoru stwierdza: „Czy jest jakaś sprzeczność z tym, aby uprawiać starą ewangelizację?"

9 czerwca 1979 roku Jan Paweł II podczas swej pielgrzymki do Polski wskazywał nie tyle na nowość, ile raczej na konieczność odnowienia ewangelizacji. Dzisiaj po 32 latach po apelu z Nowej Huty można by mówić raczej o ewangelizacji ciągłej niż o nowej ewangelizacji ${ }^{18}$. Chrześcijanie są wezwani do miłości i odpowiedzialności, do świadectwa i do odwagi, bez tego doświadczenia nie będzie gotowości pójścia na krańce świata ${ }^{19}$. Stoimy dziś w obliczu radykalnych zmian społecznych, kształtującej się nowej kultury oraz postępującego procesu sekularyzacji, spychających religię i chrześcijaństwo poza wszelki nawias. Niektórzy wskazują na pewien rodzaj „wykarczowania chrześcijańskiej pamięci” i w konsekwencji konieczność przejścia z modelu Kościoła osadzonego mocno w kulturze chrześcijańskiej do modelu pracy Kościoła osadzonego w kontekście misyjnym. Dzieje Apostolskie mogą służyć jako model ewangelizacyjny Kościoła pierwotnego, w którym przekaz Dobrej Nowiny opierał się na małych wspólnotach, które celebrowały wiarę i w pełni nią żyły ${ }^{20}$. Kościół w ramach prowadzonej ewangelizacji i realizowanej zbawczej misji w świecie przejmuje wiele z dorobku kulturowego, w którym zawarte są wartości humanistyczne, duchowe, materialne ${ }^{21}$. Coraz częściej zauważalne staje się, że świat współczesny cechują zmiany duchowe, które stanowią wyzwanie dla ewangelizacji. W ciągu wielu lat nastąpił przełom, zauważany jako zjawisko rozwijającego się sekularyzmu i radykalnego ateizmu ${ }^{22}$. Zwraca to uwagę na fakt, że istotną treścią nowej ewangelizacji staje się orędzie moralne, ponieważ za orędziem zbawienia, czyli głoszeniem Chrystusa, idzie określony porządek moralny ${ }^{23}$.

18 Por. J. Moens, Na czym polega nowa ewangelizacja, dz. cyt., s. 22-23.

19 G. Ryś, Jezusowa nowa ewangelizacja, dz. cyt., s. 16.

20 J. Moens, Na czym polega nowa ewangelizacja, dz. cyt., s. 21.

${ }_{21}$ M. Rusecki, Co to sa wartości chrześcijańskie, w: Problemy wspótczesnego Kościoła, red. M. Rusecki, Lublin 1997, s. 517.

22 D. Osvaldo i in., Wspólnoty kościelne, niezależne grupy religijne, sekty, przekł. A. Kajzerek, Warszawa 1994, s. 189.

${ }^{23}$ Por. Jan Paweł II, enc. Veritatis splendor, 35. 
Lista wyzwań sporządzona przez konferencje episkopatów jest długa - wezwania te zostały podzielone na dwie kategorie: Pierwsza odnosi się do społeczeństwa w ogólności, w którym dominują sekularyzm, hedonizm, indywidualizm, materializm, ateizm - niezauważenie Boga. Współczesny człowiek poszukuje sensu własnego życia, jednocześnie stracił on nadzieję. Zjawisko to można nazwać „kryzysem ufności w życie”. Kolejnym trudnym aspektem jest zjawisko emigracji i imigracji, ponieważ zagraża to integralności małżeństwa i rodziny, a efektem może być wykorzenienie młodych z ich środowiska życia i wiary. Trudną sprawą jest też sprowadzanie religii do prywatnej sfery życia ludzkiego. Wielkim wyzwaniem dla nowej ewangelizacji są środki masowego przekazu, które w wielu przypadkach ukazują fałszywy obraz Kościoła ${ }^{24}$.

Druga kategoria odnosi się do Kościoła. Jego wewnętrznym wyzwaniem jest stworzenie rzeczywistego „duszpasterstwa misyjnego”. Należy rozbudzić nowy dynamizm misyjny wśród katolików. Żywa obecność Chrystusa we wspólnocie Kościoła jest źródłem jego misyjnej działalności. Nowa ewangelizacja jest pewnym stanem umysłu i pełnym odwagi działaniem związanym z umiejętnością odczytania znaków czasu i interpretowania nowej sytuacji historii ludzkości. Kolejnym wyzwaniem są parafie, które muszą przejść proces nawrócenia, aby stały się ośrodkami misyjnymi. Trzecie wyzwanie dotyczy katechezy i okresu przygotowania do sakramentów, by stały się one prawdziwym miejscem ewangelizacji ${ }^{25}$. Konsekwencją ewangelizacji i jej kerygmatycznego przekazu powinno być zaproszenie do przyjęcia Jezusa jako osobistego Zbawiciela i Pana oraz wejście do wspólnoty ${ }^{26}$. Człowiek, który doświadcza jedności działania i chcenia, jedności ze słowem Bożym w codziennym postępowaniu, jest pełen pokoju i radości, jakiej świat dać nie może. Jego serce całym swoim ,ja” trwa przy Bogu. Jest on zdolny do świadectwa, bowiem jego wnętrze nie jest podzielone. Taki człowiek jest w stanie zaufać Bogu,

24 J. Moens, Na czym polega nowa ewangelizacja, dz. cyt., s. 24-25.

25 J. Moens, Na czym polega nowa ewangelizacja, dz. cyt., s. 26-27.

26 M. Stuła-Topolska, Jeśli nie my, to kamienie wołać będa, Częstochowa 2011, s. 18. 
zgodzić się, aby On przeniknął całe jego życie i był uwielbiony w jego posługiwaniu ${ }^{27}$.

Aby głosić Ewangelię, należy ponownie przyjąć Ewangelię. Sprawić, aby słowa Jezusa Chrystusa stały się żywe. W ten sposób i tylko tak będzie możliwa ewangelizacja przyciągająca niewierzących i oddalonych ${ }^{28}$.

Prawdziwa ewangelizacja ma charakter profetyczny, przełamuje niektóre skostniałe wzorce i wdziera się z odwagą i śmiałością proroków, którzy przeciwstawiali się każdej formie bałwochwalstwa. Ewangelizacja oskarża wszelkie postawy, które sprzeciwiają się jedynemu pośrednictwu Jezusa Chrystusa, i ukazuje wprost przesłanie darmowego zbawienia w Jezusie Chrystusie, prawdziwym Bogu i prawdziwym Człowieku, który jest Zbawicielem i Panem. Święty Paweł nazywał to przesłanie „Ewangelią łaski” (Dz 20, 24) ${ }^{29}$.

\section{Dokumenty Kościoła o nowej ewangelizacji}

Duch Święty przynagla do głoszenia wielkich dzieł Bożych „Nie jest dla mnie powodem do chluby to, że głoszę Ewangelię. Świadom jestem ciążącego na mnie obowiązku. Biada mi, gdybym nie głosił Ewangelii!" $(2 \text { Kor } 9,16)^{30}$. Wczytując się w początki Kościoła i badając etapy jego rozwoju oraz sposób życia i działania, nie można nie zauważyć, że ewangelizacja już tam miała swoje źródła ${ }^{31}$. Bóg otwiera przed Kościołem horyzonty ludzkości lepiej przygotowanej na ewangeliczny zasiew. Nadszedł moment zaangażowania wszystkich sił kościelnych w nową ewangelizację i w misję wśród narodów. Nikt wierzący w Chrystusa, żadna instytucja Kościoła nie może uchylić się od tego najpoważniejszego obowiązku: głoszenia Chrystusa wszystkim ludom ${ }^{32}$, uwzględniając, że ewangelizacja

27 J. Kozłowski, Pozwól się odnaleźć, Łódź 2004, s. 177.

${ }_{28}$ K. Argüello, A. Llovera, Wstęp, w: K. Argüello, Kerygmat z ubogimi w barakach, Lublin 2013, s. 13.

${ }^{29}$ Por. J. H. Prado Flores, Nowi ewangelizatorzy dla nowej ewangelizacji, dz. cyt., s. 33.

30 Jan Paweł II, enc. Redemptoris missio [dalej: RMi], 1.

31 Paweł VI, adhort. apost. Evangelii nuntiandi [dalej: EN], 15.

32 Por. RMi 3. 
winna być prowadzona z szacunkiem dla drugiego człowieka i dla głoszonej prawdy, bowiem jak uczy Sobór, prawda „tylko siłą siebie samej ogarnia umysły łagodnie, ale zarazem zdecydowanie"33.

Tak więc pomiędzy Chrystusem, Kościołem i ewangelizacją zachodzi jak najściślejszy związek. W tym „czasie Kościoła” on sam ma powierzony sobie urząd ewangelizowania ${ }^{34}$. Należy podkreślić, że w dziejach Kościoła rozmach misyjny był zawsze oznaką żywotności ${ }^{35}$, a jednocześnie jest wyrazem jego najgłębszej natury ${ }^{36}$. Kościół rozumie, że ewangelizacja jest tym samym, co zanoszenie Dobrej Nowiny do wszelkich kręgów rodzaju ludzkiego, aby przenikając je swą mocą od wewnątrz, tworzyła z nich nową ludzkość: „Oto czynię wszystko nowe”. Wszakże nie powstanie nowa ludzkość, jeśli wpierw nie powstaną nowi ludzie, odnowieni przez chrzest i przez życie według Ewangelii ${ }^{37}$.

Papież Franciszek w adhortacji Evangelii gaudium natomiast podkreśla motywacje, którym towarzyszy ewangelizacja. Pierwszą z nich jest miłość Jezusa, doświadczenie bycia zbawionym przez Niego. Prowadzi to do potrzeby mówienia o Bogu, starania się, by inni Go poznali ${ }^{38}$. Drugim motywem ewangelizacji jest osobiste doświadczenie, bycie ciągłym uczniem, dostrzeganie Jezusa żywego, towarzyszącego ${ }^{39}$. I tak głoszenie Dobrej Nowiny można określić jako pokazywanie Chrystusa Pana tym, którzy Go nie znają, jako kaznodziejstwo, katechizację, chrzest i udzielanie sakramentów ${ }^{40}$.

Papież Franciszek w adhortacji Evangelii gaudium podkreśla, że na ochrzczonych to zadanie ciąży w każdej epoce i miejscu, ponieważ „nie może być autentycznej ewangelizacji bez wyraźnego głoszenia, że Jezus jest Panem” oraz bez „prymatu głoszenia Jezusa Chrystusa w każdej działalności ewangelizacyjnej" ${ }^{41}$; ponieważ nieustanna obecność Jezusa

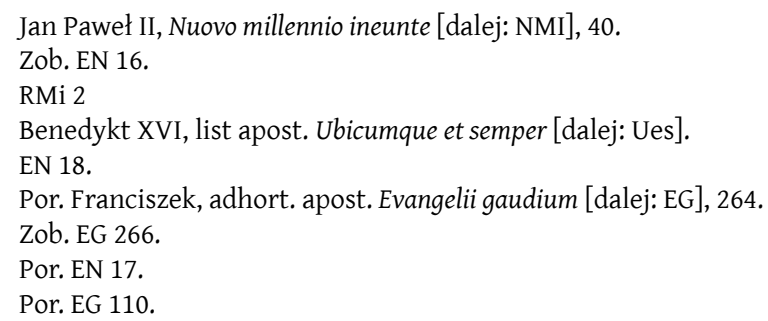


wśród swoich należy do czynności ewangelizacyjnej ${ }^{42}$. Należy podkreślić, że w dziejach Kościoła rozmach misyjny był zawsze oznaką żywotności ${ }^{43}$, a jednocześnie jest wyrazem jego najgłębszej natury ${ }^{44}$.

Celem ewangelizacji jest owa wewnętrzna przemiana. Kościół ewangelizuje, kiedy boską mocą tej Nowiny, jaką głosi, stara się przemienić sumienie poszczególnych ludzi i wszystkich razem, potem także ich działalność, a wreszcie ich życie i całe środowisko, w jakim się obracają ${ }^{45}$. W adhortacji Evangelii gaudium szczególnie akcentowana jest rola "nowości” w życiu chrześcijanina: „On może zawsze, dzięki swej nowości, odnowić nasze życie i naszą wspólnotę, a chociaż propozycja chrześcijańska przemierza mroczne epoki i słabości Kościoła, nigdy się nie starzeje"46.

Kościół wzywa do zaangażowania ewangelizacyjnego, ponieważ wskazuje chrześcijanom prawdziwy dynamizm osobistej realizacji. Ewangelizator powinien mieć pełną pociechy radość z ewangelizowania, od tych, co pierwsi zaczerpnęli swą radość od Chrystusa ${ }^{47}$.

Radość ta jest możliwa dzięki ciągłym powrotom do źródeł, ponieważ umożliwiają one odzyskanie pierwotnej świeżości Ewangelii, dzięki nim pojawiają się nowe drogi, twórcze metody, inne formy wyrazu, bardziej wymowne znaki, słowa zawierające nowy sens dla dzisiejszego świata. W rzeczywistości każda autentyczna działalność ewangelizacyjna jest zawsze "nowa”"48.

Synod biskupów z 1974 roku zwraca uwagę na rolę Ducha Świętego w ewangelizacji, wyraził również życzenie, aby dogłębniej badano naturę i sposób działania Boskiego Pocieszyciela. Zachęcali głosicieli Ewangelii, aby nieustannie z najwyższą wiarą i żarliwością modlili się do Ducha Bożego, powierzali się Jego kierownictwu jako głównemu sprawcy ich zamiarów i planów oraz ich przedsięwzięć odnoszących się do dzieła

42 Zob. EN 6.

43 RMi 2

44 Ues.

45 EN 18.

46 EG 11.

47 EG 10.

${ }^{48}$ Zob. EG 11. 
ewangelizacji ${ }^{49}$. Ciągłość tej myśli odnajdujemy także u Benedykta XVI $\mathrm{w}$ liście apostolskim $\mathrm{w}$ formie motu proprio Ubicumquet et semper, gdzie na nowo zwraca uwagę, by cały Kościół, odradzając się w mocy Ducha Świętego, zwrócił się do współczesnego świata z nowym zapałem misyjnym, by krzewić nową ewangelizację ${ }^{50}$. Należy pamiętać, że w każdej formie ewangelizacji prymat należy zawsze do Boga, który zechciał powołać do współpracy z Nim i pobudzać mocą swego Ducha. Prawdziwa nowość to ta, którą sam Bóg chce w sposób tajemniczy wprowadzić, którą On inspiruje, którą On prowokuje, którą On kieruje i której towarzyszy na tysiąc sposobów ${ }^{51}$.

Na XII Zwyczajnym Zgromadzeniu Synodu Biskupów w 2012 roku, którego owocem był dokument Lineamenta, szczególnie podkreśla się rolę słowa Bożego, będącego nieodzownym narzędziem ewangelizacji, dlatego zwraca się uwagę na różne formy przekazu słowa, a zarazem wciąż nowe wymagania ze strony wiernych w różnym wieku i różnej sytuacji duchowej, kulturowej i społecznej ${ }^{52}$. Kościół powołany jest do podjęcia posługi trudnego dialogu, by dotrzeć ze słowem Bożym do każdego człowieka. Konieczna staje się ewangelizacja, która rzuciłaby światło na nowe sposoby kontaktu z Bogiem, z innymi ludźmi, ze środowiskiem i która odbudowałaby fundamentalne wartości. Trzeba dojść tam, gdzie kształtują się nowe przesłania i wzorce ${ }^{53}$.

Paweł VI w adhortacji Evangelii nuntiandi zwraca uwagę na środki ewangelizacyjne. Szczególnie podkreśla rolę świadectwa potwierdzonego życiem, ponieważ ono uwidacznia wierność Jezusowi ${ }^{54}$. Innym środkiem jest nauczanie katechetyczne, tę naukę należy podawać w tym celu, żeby kształtować obyczaje chrześcijańskie ${ }^{55}$. Ważnym środkiem są także mass

\footnotetext{
49 EN 75.

50 Por. Ues.

51 EG 12.

52 XIII Zwyczajne Zgromadzenie Ogólne Synodu Biskupów, Nowa ewangelizacja dla przekazu wiary chrześcijańskiej, w: Lineamenta [dalej: Lm], 23.

53 EG 74.

54 Zob. EN 43.

55 Zob. EN 44.
} 
media; przy pierwszym zapoznaniu z wiarą, w nauczaniu katechetycznym czy w dalszym pogłębianiu wiary nie może braknąć ich pomocy ${ }^{56}$.

Dużą rolę w dziele nowej ewangelizacji przypisuje się Maryi, ponieważ jest Ona wzorem macierzyńskiej miłości, jaka powinna ożywiać wszystkich tych, którzy w dziele misyjnego apostolstwa Kościoła pracują nad odrodzeniem człowieka ${ }^{57}$. Maryja potrafi dostrzec wokół siebie pilne potrzeby codziennego życia i brać je sobie do serca, pamiętając, że to, co otrzymuje w darze od Syna, jest darem dla wszystkich. Ona uczy, by na słowo życia nie patrzeć z zewnątrz, jak widzowie, lecz żyć, pozwalając się prowadzić Duchowi Świętemu, który przebywa $\mathrm{w}$ wierzących ${ }^{58}$.

\section{Adresaci nowej ewangelizacji}

Nowa ewangelizacja to wymiar ewangelizacji skierowany do ochrzczonych ludzi, którzy porzucili praktyki chrześcijańskie ${ }^{59}$, którzy gdzieś się zagubili, zneutralizowali lub spłaszczyli doświadczenie własnego chrztu $^{60}$. Obecnie zauważalny jest kryzys moralny, który jest przede wszystkim skutkiem kryzysu prawdy i zafałszowania wolności, co powoduje, że człowiek chciałby samodzielnie decydować o dobru i złu swoich czynów. Warto zwrócić uwagę, że kryzys prawdy nie dotyka tylko życia moralnego, ale wyznacza perspektywę szerszą, bowiem Prawdą jest dla nas Jezus Chrystus, a więc jest to także kryzys prawd wiary ${ }^{61}$.

Dobra Nowina skierowana jest do tych, którzy nie znają mocy, jaką daje wiara, nawet jeśli teoretycznie wiedzą wiele o Bogu; nawet jeśli żyją w świecie, który przesiąknięty jest religią i wypełniony związanymi z nią

$56 \quad$ EN 45.

$57 \quad$ RMi 92.

58 Lm 12.

59 Zob. G. Ryś, Kierunki nowej ewangelizacji..., dz. cyt., s. 3.

60 Zob. G. Ryś, Jezusowa nowa ewangelizacja, dz. cyt., s. 13.

61 K. Jeżyna, Moralne przesłanie nowej ewangelizacji. Wezwanie do odnowy Kościoła i świata, Lublin 2002, s. 67. 
instytucjami, znają prawo religijne i „uczonych w Piśmie”, może nawet "chodzą do synagogi"62.

Warto zwrócić uwagę na słowa św. Pawła, który mówi stanowczo o potrzebie przepowiadania, ponieważ Pan chciał dotrzeć do innych również dzięki naszemu słowu (por. Rz 10, 14-17). Nasz Pan słowem zdobył serce ludzi. Przychodzili Go słuchać zewsząd (por. Mk 1, 45). Pozostawali zdumieni, wchłaniając Jego naukę (por. Mk 6, 2). Czuli, że przemawiał do nich jako mający władzę (por. Mk 1, 27). Dzięki słowu Apostołowie, których ustanowił, „aby Mu towarzyszyli, by mógł wysyłać ich na głoszenie nauki" (Mk 3,14), przyciągnęli na łono Kościoła wszystkie narody (por. Mk 16, 15.20) ${ }^{63}$.

Każdy ochrzczony jest wezwany, by wzrastać jako ewangelizator. Jednocześnie stara się o lepszą formację, o pogłębienie miłości i jaśniejsze świadectwo Ewangelii, jak również świadectwo o zbawczej miłości Pana, który niezależnie od niedoskonałości ofiaruje swoją bliskość, swoje słowo, swoją moc, i nadaje sens życiu. Życie nie jest takie samo bez Niego, dlatego ten, który to odkrył, co pomaga żyć i co daje nadzieję, powinien przekazywać innym. Ludzka niedoskonałość nie powinna stanowić wymówki. Przeciwnie, misja stanowi stały bodziec, aby nie godzić się z przeciętnością i stale wzrastać. Świadectwo wiary, do złożenia którego każdy chrześcijanin jest wezwany, zakłada stwierdzenie podobne do słów św. Pawła: «Nie [mówię], że już[to] osiągnąłem i już się stałem doskonały, lecz pędzę, abym też [to] zdobył, [...] pędzę ku wyznaczonej mecie» (Flp 3, 12. 14) ${ }^{64}$.

Nie wystarczy troska ewangelizatora o dotarcie do każdej osoby, a Ewangelia głoszona jest także całym kulturom, teologia, nie tylko teologia pastoralna, nabiera szczególnego znaczenia $\mathrm{w}$ dialogu z innymi naukami i ludzkimi doświadczeniami. To wszystko pozwala lepiej zastanowić się, jak dotrzeć z propozycją Ewangelii do wszystkich adresatów $\mathrm{w}$ wielorakich kontekstach kulturowych, biorąc pod uwagę ewangelizacyjny cel $^{65}$.

\footnotetext{
2 Por. K. Jeżyna, Moralne przesłanie nowej ewangelizacji.., dz. cyt., s. 16.

3 EG 136.

64 EG 121.

65 EG 133.
} 
W adhortacji Evangelii gaudium Franciszek odwołał się do słów Pawła VI, który stwierdził, że wierni ,wiele oczekują od tego przepowiadania i korzystają, byle było proste, przejrzyste, bezpośrednie, przystosowane”. Prostota wiąże się z językiem, który powinien być zrozumiały dla adresatów, żeby nie stwarzać ryzyka mówienia w próżni. Istnieją słowa właściwe dla teologii lub katechezy, których sens nie jest zrozumiały dla większości chrześcijan. Największym ryzykiem dla kaznodziei jest przyzwyczaić się do swojego języka i uważać, że wszyscy inni się nim posługują i rozumieją go spontanicznie. Prostota i jasność to dwie różne rzeczy ${ }^{66}$.

Ewangelizacja wymaga konkretnego zainteresowania się światem środków komunikacji społecznej. Są one drogą, na której, zwłaszcza w nowych mediach, spotykają się liczni ludzie, ich pytania i oczekiwania. Miejscem, w którym często formują się sumienia i które wyznacza rytm i treść życia; nową sposobnością dotarcia do serca człowieka. Ewangelizacja wynika z przekonania o prawdzie Chrystusa. Ewangelia Jezusa to pokój i radość, a Jego uczniowie z radością uznają to, co prawdziwego i dobrego potrafił dostrzec w świecie stworzonym przez Boga duch religijny ludzi i wyraził, nadając kształt różnym religiom ${ }^{67}$.

Ewangelizacja zaczyna się wtedy, gdy docieramy do osoby. Paweł VI w Evangelii nuntiandi mówi o tym, że ewangelizacja to spotkanie osoby Jezusa Chrystusa z osobą każdego człowieka. Dopóki nie zejdziemy na ten poziom indywidualny, to, co robimy, jest preewangelizacją ${ }^{68}$, która staje się szansą dla ludzi, aby mogli na nowo stać się chrześcijanami żyjącymi w pełni Ewangelią, czyli osobami trwającymi w osobowej relacji z Chrystusem. Jest on bowiem celem wszelkiej ewangelizacji, a jednocześnie spotkanie z Chrystusem jako osobą jest koniecznym warunkiem, aby samemu stać się ewangelizatorem. Dlatego nowej ewangelizacji nigdy nie można oddzielać od żywej osoby Chrystusa: być chrześcijaninem to znaczy spotkać się z osobą ${ }^{69}$.

66 EG 158.

$67 \quad \operatorname{Lm} 6$.

68 G. Ryś, Kierunki nowej ewangelizacji..., dz. cyt., s. 4.

69 J. Moens, Na czym polega nowa ewangelizacja, dz. cyt., s. 20. 
Jedynie dzięki temu spotkaniu lub ponownemu spotkaniu z miłością Bożą, które przemienia się w pełną szczęścia przyjaźń, człowiek zostaje uwolniony od wyizolowanego sumienia i skoncentrowania się na sobie. Staje się w pełni ludzki, gdy przekracza ludzkie ograniczenia, gdy pozwala Bogu poprowadzić się, aby dotrzeć do prawdziwej istoty. W tym tkwi źródło działalności ewangelizacyjnej. Jeśli bowiem ktoś przyjął tę miłość przywracającą mu sens życia, czyż może zrezygnować z pragnienia, by podzielić się tym z innymi? ${ }^{70}$. Uczeń, który przeżywa proces ewangelizacji na sobie, sam się staje ewangelizatorem ${ }^{71}$.

Żeby być ewangelizatorem dusz, trzeba rozwinąć duchowe upodobanie pozostania blisko życia ludzi. Misja ta łączy się z miłością do Jezusa, ale jednocześnie z miłością do Jego ludu. Nie można pominąć, że każdy ewangelizator jest wzięty z ludu i posłany do ludu, tak że nie można zrozumieć swojej tożsamości bez przynależności do $\mathrm{Niego}^{72}$. Dembowski zwraca uwagę, że gdy jest mowa o nowej ewangelizacji, to zwykle dotyczy to dwóch słów: kerygmatu i katechezy. Kerygmatem jest orędzie o Jezusie Chrystusie, Zbawicielu i Panu. Głoszenie kerygmatu jest świadczeniem: widzieliśmy Pana, spotkałem Jezusa. Natomiast katecheza jest wyjaśnieniem i wzbogaceniem wiedzy. Przez kerygmat człowiek na nowo się rodzi (por. J 3, 3-7), staje się żywy. Dopiero żywy człowiek jest w stanie przyjąć te wszystkie prawdy, które są głoszone w katechezie w najszerszym tego słowa znaczeniu ${ }^{73}$. Głoszenie to pierwszy krok, a katecheza przychodzi dopiero później ${ }^{74}$. Dembowski mówi o tym, że katechizacja bez ewangelizacji, bez przyjęcia Jezusa Chrystusa, jest karmieniem nieboszczyków. Chodzi więc o to, by najpierw przyjąć Jezusa Chrystusa, który jest Drogą, Prawdą i Życiem ${ }^{75}$.

Jeśli ktoś chce być ewangelizatorem, jest mu potrzebna kontemplacja. Jego zapał ma wynikać z tego, że czyta zamysł Boży wobec świata,

\footnotetext{
EG 8.

G. Ryś, Kierunki nowej ewangelizacji..., dz. cyt., s. 8.

EG 268.

B. Dembowski, $W$ wolności i posłuszeństwie, Włocławek 2000, s. 45-46.

J. H. Prado Flores, Nowi ewangelizatorzy dla nowej ewangelizacji, dz. cyt., s. 62.

B. Dembowski, W wolności i posłuszeństwie, dz. cyt., s. 48.
} 
ponieważ go odczytuje i w posłuszeństwie przyjmuje, i w posłuszeństwie sam go podejmuje ${ }^{76}$.

Propositiones mówi o tym, że ewangelizator musi być uformowany duchowo, to oczywiste; jest to streszczone w zwrotcie „trynitarna chrystocentryczność". Czyli wszystko jest skoncentrowane na Chrystusie, ale Chrystus jest widziany w perspektywie życia całej Trójcy. Z tej prawdy wynika cała duchowość ewangelizatora ${ }^{77}$.

Pomiędzy ewangelizacją i promocją ludzką, czyli rozwojem i wyzwoleniem, zachodzą wewnętrzne powiązania: więzy natury antropologicznej, jako że człowiek ewangelizowany nie jest bytem abstrakcyjnym, ale osobą uwikłaną w sprawy społeczne i gospodarcze; także więzy natury teologicznej, gdyż planu stworzenia nie można oddzielić od planu odkupienia, który sięga aż do bardzo konkretnych sytuacji, zwalczania krzywdy i zaprowadzania sprawiedliwości; są także więzy natury najbardziej ewangelicznej, mianowicie porządek miłości: bo jak można głosić nowe przykazanie bez popierania razem ze sprawiedliwością i pokojem prawdziwego i braterskiego postępu człowieka? Dlatego należy nadmienić, że jest rzeczą niedopuszczalną, aby w ewangelizacji „można było lub należało lekceważyć najwyższą wagę [...] owych problemów tak dziś nabrzmiałych, które dotyczą sprawiedliwości, wyzwolenia, postępu i pokoju w świecie. Bo gdyby się tak działo, to zapomni się także naukę Ewangelii o miłości względem bliźniego, cierpiącego i potrzebującego"78.

Głoszący Ewangelię powinni bez lęków otworzyć się na działanie Ducha Świętego. W dniu Pięćdziesiątnicy Duch sprawił, że apostołowie wyszli ze swych ograniczeń i zostali przemienieni w głosicieli wielkich dzieł Bożych, których każdy zaczyna rozumieć w swoim własnym języku. Ponadto Duch Święty obdarza siłą do głoszenia nowości Ewangelii śmiało, na głos, w każdym czasie i miejscu, także pod prąd. Jezus pragnie ewangelizatorów głoszących Dobrą Nowinę nie tylko słowem, ale przede wszystkim życiem przemienionym obecnością Bożą ${ }^{79}$.

76 G. Ryś, Kierunki nowej ewangelizacji..., dz. cyt., s. 9.

77 G. Ryś, Kierunki nowej ewangelizacji..., dz. cyt., s. 10.

78 EN 31.

79 EG 259. 
Ewangelizatorzy dzisiejszych czasów to ci, którzy się modlą i pracują. Z punktu widzenia ewangelizacji nie służą im ani mistyczne propozycje bez mocnego zaangażowania społecznego i misyjnego, ani przemówienia oraz działania społeczne i duszpasterskie bez duchowości przemieniającej serce. Trzeba zawsze dbać o wewnętrzną przestrzeń, nadającą sens chrześcijańskiemu zaangażowaniu i aktywności. Bez dłuższych chwil adoracji, modlitewnego spotkania ze Słowem, zadania łatwo pozbawione zostają sensu. Kościół ma ogromną potrzebę oddychania płucami modlitwy ${ }^{80}$.

Nowa ewangelizacja w Kościele ma jeden zasadniczy cel, którym jest ukazanie miłości Boga, objawiającego się w Jezusie Chrystusie. Dlatego Kościół wciąż podejmuje wyzwanie głoszenia Chrystusa wszystkim ludziom, będąc w ciągłej gotowości słuchania Ducha Świętego. Dzięki temu nowa ewangelizacja umożliwia współczesnemu pokoleniu poznanie niezgłębionego bogactwa Chrystusa.

80 Por. EG 262. 


\section{Summary}

\section{Nowa ewangelizacja w Kościele}

Ewangelizacja była znana na przestrzeni wieków. Pierwsze posyłanie uczniów ma znamiona głoszenia dobrej nowiny. Liczne dokumenty Kościoła usiłowały zdefiniować dzieło ewangelizacji i nadać mu nowe znaczenie. Pierwszym dokumentem jest dekret o działalności misyjnej Kościoła ad gentes Soboru Watykańskiego II, w którym czytamy, że Chrystus został posłany, „aby ukazywać miłość Bożą i zaszczepiać ją wszystkim ludziom i narodom" "1. Misja ad gentes ma na uwadze tych, którzy nie słyszeli o Chrystusie. Posoborowe nauczanie Kościoła coraz częściej wskazuje, że każdy ochrzczony jest wezwany do głoszenia dobrej nowiny. Nowa ewangelizacja to głoszenie orędzia zbawienia na nowe sposoby, to wychodzenie ku współczesnym z nowymi formami i środkami. Jednak najskuteczniejsze jest osobiste świadectwo.

Niniejszy artykuł ukazuje zarys, pojęcia i próbę zdefiniowania nowej ewangelizacji na tle dostępnych opracowań, zwrócenie uwagi na dokumenty Kościoła, w których temat nowej ewangelizacji poruszany jest w sposób wieloaspektowy. Następnie wzięci są pod uwagę adresaci Dobrej Nowiny.

słowa kluczowe: nowa ewangelizacja, Dobra Nowina, chrześcijanie

\section{New Evangelization in the Church}

Evangelization was known over centuries and well know in the history. First sending off the apostles, has characteristics of the proclamation of the Good News. Several Church's documents tried to define the process of evangelization and to give it a new meaning. The first document is the Decree ad gentes on the mission activity of the Church of the Second Vatican Council, in which we read, that Christ was sent "to reveal and to communicate the love of God to all men and nations" The mission ad gentes is concerned about those who never heard about Christ. Postsynodal Magisterium of the Church more often indicates that every baptised person is called to proclaim the Good News. The new evangelization means proclamation of the salvation in new way, it means to go out to modern man with modern forms and means of communication. Yet the most effective is one's personal experience.

This article shows an outline, concepts and attempts to define new evangelization in the light of the available materials, with particular attention to the Church's

${ }_{81}$ Por. Sobór Watykański II, dekret Ad gentes divinitus, 10.

82 AG 10. 
documents which treat new evangelization in different perspectives. Then taken into account are the recipients of the Good News.

keywords: new evangelization, Good News, Christians

\section{Bibliografia}

Argüello K., Kerygmat z ubogimi w barakach, Lublin 2013.

Benedykt XVI, Motu proprio Ubicumque et semper.

Chiaro M., Per una nuova evangelizzazione, „Testimoni” (2011) nr 6, s.1-3.

Dembowski B., W wolności i posłuszeństwie, Włocławek 2000.

Ewangelia w świecie - Orędzie Synodu Biskupów do ludu Bożego, http://nowaewangelizacja.org/ewangelia-w-swiecie-oredzie-synodu-biskupow-do-ludu-bozego/

(09.03.2017).

Franciszek, Adhortacja apostolska Evangelii gaudium.

Jan Paweł II, List apostolski Nuovo millennio ineunte.

Jan Paweł II, Encyklika Redemptoris missio.

Jan Paweł II, Encyklika Veritatis splendor.

Jeżyna K., Moralne przesłanie nowej ewangelizacji. Wezwanie do odnowy Kościoła i świata, Lublin 2002.

Kozłowski J., Pozwól się odnaleźć, Łódź 2004.

Osvaldo D. i in., Wspólnoty kościelne, niezależne grupy religijne, sekty, przekł.

A. Kajzerek, Warszawa1994.

Paweł VI, Adhortacja apostolska Evangelii nuntiandi.

Pismo Święte Starego i Nowego Testamentu, Poznań 2009.

Prado Flores J. H., Nowi ewangelizatorzy dla nowej ewangelizacji, przekł. B. Jakubowski, Poznań 2013.

Rusecki M., Co to sa wartości chrześcijańskie, w: Problemy wspótczesnego Kościoła, red. M. Rusecki, Lublin 1997, s. 515-530.

Ryś G., Kierunki nowej ewangelizacji na podstawie wskazań Synodu Biskupów, „Via Consecrata" (2013) nr 1-2, s. 3-11.

Sobór Watykański II, Dekret Ad Gentes Divinitus.

Stuła-Topolska M., Jeśli nie my, to kamienie wołać będa, Częstochowa 2011.

Zdrzałek J., Nawrócenie jako droga nowej ewangelizacji, „Via Consecrata” (2013) nr 1-2, s. 52.

Zespołu Konferencji Episkopatu Polski do spraw Nowej Ewangelizacji, Nowa ewangelizacja - kerygmatyczny impuls w Kościele, Gubin 2012.

XIII Zwyczajne Zgromadzenie Ogólne Synodu Biskupów, Nowa ewangelizacja dla przekazu wiary chrześcijańskiej, Lineamenta, Watykan 2011. 